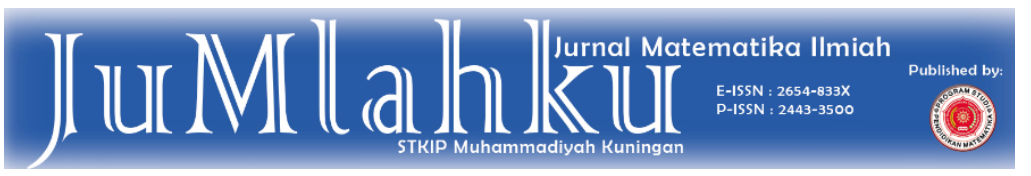

Submited: 2021-10-02

Published: 2021-11-28

\title{
Meningkatkan Kemampuan Pemahaman Serta Menurunkan Kecemasan Matematis Melalui Strategi Brain Based Learning
}

Dea Siti Fikriyaha ${ }^{a}$ Gitta Maharanib ${ }^{b}$ M. Gilang Agustian Nugrahac, Melinda Putri Mubarikad

\author{
a Ruangguru \\ b SMK Bina Karya 1 Karawang \\ c SMP Negeri 1 Bayah \\ d Pascasarjana Unpas
}

Corresponding Author : deasitif14@gmail.com ${ }^{\mathrm{a}}$

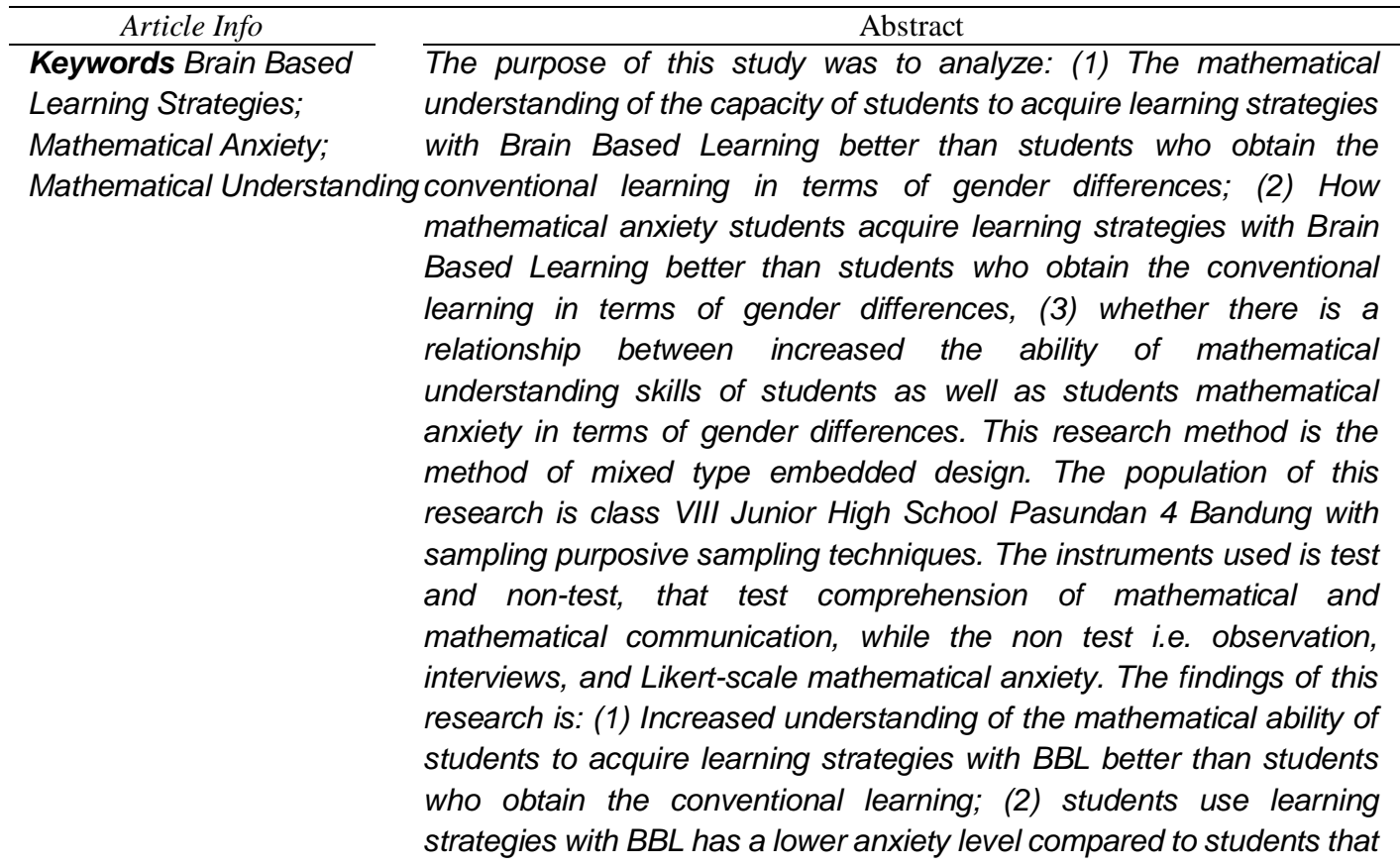


using conventional learning; (3) There was no relationship between mathematical anxiety students against the ability of mathematical understanding.

Kata Kunci: kecemasan matematis; pemahaman matematis; strategi Brain Based Learning

\begin{abstract}
Abstrak
Tujuan dari penelitian ini adalah untuk menganalisis: (1) peningkatan kemampuan pemahaman matematis siswa yang memperoleh pembelajaran dengan strategi Brain Based Learning lebih baik daripada siswa yang memperoleh pembelajaran konvensional ditinjau dari perbedaan gender, (2) Bagaimana kecemasan matematis siswa yang memperoleh pembelajaran dengan strategi Brain Based Learning lebih baik daripada siswa yang memperoleh pembelajaran konvensional ditinjau dari perbedaan gender, (3) Apakah terdapat hubungan antara peningkatan kemampuan pemahaman matematis serta kecemasan matematis siswa ditinjau dari perbedaan gender. Metode penelitian menggunakan metode campuran (mixed methods) tipe embedded design. Populasi penelitian adalah kelas VIII SMP Pasundan 4 Bandung dengan pengambilan sampel menggunakan teknik purposive sampling. Instrumen yang digunakan adalah tes dan non tes, yaitu tes pemahaman matematis, sedangkan non tes yaitu observasi, wawancara. Hasil penelitian ini adalah: (1) Peningkatan kemampuan pemahaman matematis siswa yang memperoleh pembelajaran dengan strategi Brain Based Learning lebih baik daripada siswa yang memperoleh pembelajaran konvensional ditinjau dari perbedaan gender; (2) Siswa yang menggunakan pembelajaran dengan strategi Brain Based Learning mempunyai tingkat kecemasan yang lebih rendah dibandingkan dengan siswa yang menggunakan pembelajaran konvensional; (3) Tidak terdapat hubungan antara kecemasan matematis siswa terhadap kemampuan pemahaman matematis siswa.
\end{abstract}

\section{PENDAHULUAN}

Tujuan pembelajaran matematika diajarkan di sekolah pada butir pertama mengisyaratkan bahwa kemampuan pemahaman matematis merupakan syarat untuk mencapai pemecahan masalah, sehingga kemampuan pemahaman matematis memiliki peran penting dalam membentuk dan menunjang kemampuan- kemampuan matematis yang lainnya. Sejalan dengan pendapat Sumarmo (Rosmanita, 2014:160) menyatakan bahwa pemahaman matematis penting dimiliki siswa karena diperlukan untuk menyelesaikan masalah matematika, masalah dalam disiplin ilmu lain, dan masalah dalam kehidupan sehari-hari, yang merupakan visi pengembangan 
pembelajaran matematika untuk memenuhi kehidupan masa kini. Siswa yang memliki pemahaman konsep matematika yang bagus akan mengetahui lebih dalam tentang ide-ide matematika yang rmasih terselubung. Siswa juga dapat memecahkan masalah-masalah baru, memberikan pendapat dan menjelaskan suatu konsep. Akan tetapi berdasarkan pengalaman dan pengamatan di sekolah, masih banyak siswa yang masih mengalami kesulitan dalam memahami materi matematika itu sendiri. Beberapa masalah yang memerlukan pemahaman konsep matematika belum dikuasai secara optimal oleh siswa, seperti lemahnya pemahaman konsep yang satu dengan konsep yang lain yang diperlukan untuk menyelesaikan masalah matematika (Kariadinata dkk., 2019:32).

Rendahnya pemahaman matematis siswa dapat dipengaruhi oleh beberapa faktor. Salah satunya adalah kecemasan matematika siswa. Penelitian Anita (2011) mengungkapkan bahwa tinggi rendahnya kemampuan berpikir siswa dipengaruhi oleh kecemasan matematika yang sering disebut mathematics anxiety. Nugraha (Rosmanita, 2014:161) memberikan pengertian bahwa cemas pada matematika berarti cemas pada mata pelajaran matematika dan yang berhubungan dengannya, seperti cemas tidak mengerjakan soal, cemas pada saat ditanya oleh guru. Beberapa hasil penelitian menyatakan bahwa kecemasan matematika merupakan salah satu faktor yang memiliki hubungan negatif dengan prestasi belajar. Maloney dan Beilock (2012:405) menyatakan bahwa efek dari sikap yang negatif terhadap matematika meningkatkan kecemasan matematis, yang berdampak pada proses pembelajaran. Kedua pernyataan menunjukkan hubungan antara kecemasan matematika dan sikap. Saya telah mengamati terlalu sering, sikap negatif terhadap matematika yang diperkuat oleh stereotip gender, serta sikap siswa, keyakinan bahwa mereka tidak membutuhkan matematika atau keluarga mereka non-matematis. Sejalan dengan itu, Hellum-Alexander (2010) dalam penelitiannya menemukan bahwa kecemasan matematis juga berpengaruh terhadap kemampuan matematis dan termasuk di dalamnya adalah kemampuan pemahaman matematis.

Kemampuan pemahaman hanya dapat berkembang dan penurunan kecemasan siswa berkurang jika proses pembelajaran mendukung keterlibatan siswa secara aktif dalam pembelajaran. Oleh karena itu guru 
harus berinovasi untuk menentukan strategi yang tetap dalam pembelajaran matematika sehingga pembelajaran dapat berjalan dengan baik dan sesuai dengan tujuan yang diharapkan. Salah satu upaya untuk meningkatkan pemahaman matematis siswa serta menurunkan tingkat kecemasan siswa adalah dengan menggunakan strategi pembelajaran yang tepat. Strategi pembelajaran yang dirasa tepat adalah strategi Brain Based Learning. Strategi Brain Based Learning atau dikenal dengan pembelajaran berbasis kemampuan otak adalah pembelajaran yang diselaraskan dengan cara otak secara alamiah untuk belajar. Widyantara dkk (2014:4) menyatakan bahwa pembelajaran berbasis otak merupakan suatu pembelajaran yang mengaktifkan siswa untuk dapat membangun sendiri pengetahuannya dengan memanfaatkan dan memberdayakan kemampuan otak yang dimiliki siswa.

Penerapan Strategi Brain Based Learning $(B B L)$ atau pembelajaran berbasis kemampuan otak didalam proses pembelajaran lebih menekankan kepada aktivitas siswa dengan cara mengoptimalkan kerja otak. Penyeimbangan antara otak kanan dan otak kiri dapat dilakukan bersama dengan senam otak diawal pembelajaran. Hal ini dilakukan agar siswa merasa senang sebelum proses pembelajaran dimulai. Terkait dengan kemampuan pemahaman matematis serta kecemasan matematis, tiap siswa memiliki kemampuan yang berbeda-beda. Perbedaan yang paling sering diteliti ialah perbedaan berdasarkan gender.

Berdasarkan uraian latar belakang di atas, peneliti ingin menganalisis apakah ada peningkatan pemahaman matematis dan penurunan kecemasan matematis siswa dalam pembelajaran matematika dengan menggunakan Strategi Brain Based Learning ditinjau dari perbedaan gender..

\section{METODE}

Metode penelitian yang akan digunakan dalam penelitian ini adalah metode quasi eksperimen yaitu gabungan antara penelitian kuantitatif dan penelitian kualitatif. Adapun metode campuran yang digunakan adalah The Embedded Design. Metode penelitian model embedded merupakan metode penelitian yang mengkombinasikan penggunaan metode penelitian kuantatif dan kualitatif secara 
simultan atau bersama-sama tetapi bobot metodenya berbeda.

Berikut adalah metode penelitian Embedded Design menurut Creswell (Indrawan dan Yaniawati, 2014):

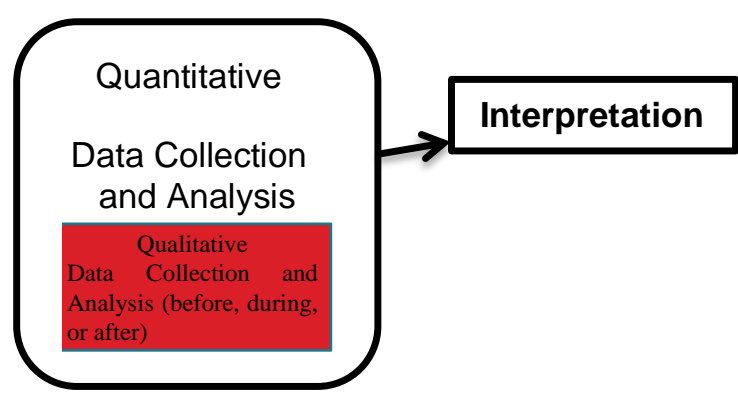

Gambar 1

Metode Penelitian tipe Embedded Design

Dalam penelitian ini, penelitian metode kuantitatif digunakan untuk memperoleh data berkaitan dengan kemampuan pemahaman matematis siswa setelah memperoleh pembelajaran dengan strategi Brain Based Learning (BBL), sedangkan penelitian kualitatif digunakan untuk memperoleh data berkaitan dengan kecemasan matematis siswa yang memperoleh pembelajaran dengan strategi Brain Based Learning (BBL).

Populasi pada penelitian ini adalah seluruh siswa SMP Pasundan 4 Bandung kelas VIII semester Ganjil tahun ajaran 2017/2018. Adapun yang menjadi pertimbangan pemilihan lokasi penelitian adalah rendahnya kemampuan pemahaman, komunikasi matematis dan tingginya kecemasan siswa dalam belajar matematika di kelas VIII SMP Pasundan 4 Bandung. Sedangkan sampel penelitiannya adalah siswa kelas VIII SMP Pasundan 4 Bandung sebanyak 2 kelas dengan masingmasing kelas terdapat 35 siswa. Satu kelas sebagai kelas eksperimen dan satu kelas nya lagi sebagai kelas kontrol. Pengambilan sampel ini ditentukan berdasarkan teknik Purposive Sampling. Adapun instrumen penelitian ini adalah 1) Tes kemampuan pemahaman matematis siswa. Sebelum soal tes dipergunakan dalam penelitian, soal tes diujicobakan terlebih dahulu. Analisis uji 
coba tes meliputi validitas, reliabilitas, daya pembeda (DP) dan Indeks kesukaran (IK), 2) Angket kecemasan matematis siswa, skala motivasi yang digunakan berupa pertanyaan tertutup dengan menggunakan skala Likert 5 alternatif jawaban. Tiap item dibagi kedalam lima skala, yaitu sangat setuju, setuju, tidak tentu, tidak setuju, dan sangat tidak setuju. Setiap pertanyaan positif diberi bobot 5, 4, 3 , 2 , dan 1, sedangkan pernyataan negatif diberi bobot sebaliknya, 3) Wawancara, dilakukan terhadap siswa kelas VIII SMP Pasundan 4 Kota Bandung yang pembelajarannya menggunakan strategi Brain Based Learning. Wawancara ini dilakukan untuk mengetahui tanggapan atau pendapat siswa terhadap strategi Brain Based Learning. 4) Lembar observasi, observasi dilakukan pada saat pelaksanaan proses pembelajaran. Lembar observasi digunakan untuk mengukur tingkat aktivitas siswa dan guru dalam melaksanakan pembelajaran.

Teknik pengumpulan data yang akan dilakukan peneliti adalah teknik pengumpulan data yang bersifat menggabungkan berbagai teknik pengumpulan data dan sumber data yang telah ada yaitu teknik pengumpulan dan triangulasi. Triangulasi yang akan dilakukan berupa triangulasi teknik, yakni peneliti melakukan pengumpulan data yang berbeda-beda untuk mendapatkan data dari sumber yang sama.

Adapun teknik analisis data yang digunakan dalam penelitian ini adalah analisis data tes awal (pretes) kemampuan pemahaman matematis kelompok eksperimen dan kelompok kontrol, dengan menggunakan SPSS 25.0 for Windows yaitu: 1) Menghitung rata-rata, variansi dan simpangan baku data hasil pretes dan postes kelas eksperimen dan kelas kontrol; 2) Melakukan uji normalitas dari data hasil pretes kelas eksperimen dan kelas kontrol dengan menggunakan uji Shapiro-Wilk pada taraf signifikan $5 \%(\alpha=0,05) ; 3)$ Melakukan uji signifikansi perbedaan dua rata-rata dengan uji anova satu. Kemudian analisis data tes akhir (postes) kemampuan pemahaman matematis kelompok eksperimen dan kelompok kontrol, yaitu: 1) 
Melakukan uji normalitas dari data hasil postes kelas eksperimen dan kelas kontrol dengan menggunakan uji Shapiro-Wilk pada taraf signifikan $5 \%(\alpha=0,05) ; 2)$ Melakukan uji homogenitas dua varians antara data postes kelas eksperimen dan kelas kontrol dengan uji Levene dengan taraf signifikansi $0,05 ; 3)$ Melakukan uji perbedaan rerata nilai postes kemampuan pemahaman matematis dengan uji-t.

Setelah itu dilakukan Analisis data skor gain ternormalisasi dilakukan untuk menguji hipotesis, apakah peningkatan kemampuan pemahaman dan

komunikasi matematis kelompok eksperimen lebih baik dari kelompok kontrol atau tidak dengan rumus g-faktor (N-Gain) menurut Meltzer \& Hake. Sebelum data di analisis dilakukan uji prasyarat terlebih dahulu, yaitu uji normalitas dan uji homogenitas, yaitu: 1) Uji normalitas N-Gain dihitung dengan menggunakan uji Shapiro Wilk; 2) Kemudian, karena data N-Gain tidak berdistribusi normal, maka dilakukan uji non parametrik yaitu Kruskal-Wallis untuk mengetahui signifikan kesamaan data $\mathrm{N}$ -
Gain kemampuan pemahaman matematis antara kedua kelas; 3) Data skor N-Gain memenuhi syarat kenormalan, maka dilanjutkan dengan uji Levene; 4) Data berditribusi normal dan homogen, maka selanjutnya dilakukan uji Anova dua jalur.

Analisis data kecemasan matematis siswa menggunakan skala Likert. Untuk melihat apakah terdapat perbedaan yang signifikan pada skor kecemasan matematis siswa yang menggunakan metode Brain Based Learning dengan siswa yang menggunakan pembelajaran konvensional, dilakukan uji kesamaan dua rerata. Sebelum dilakukan uji dua rerata harus terlebih dahulu dilakukan uji normalitas dan uji homogenitas dua varians, yaitu: 1) Uji normalitas terhadap dua kelas tersebut dilakukan dengan uji Shapiro-Wilk dengan taraf signifikansi 0,$05 ; 2)$ homogenitas dua varians antara data kecemasan siswa kelas eksperimen dan kelas kontrol menggunakan uji Levene dengan taraf signifikansi 0,05; 3) Kedua kelas tersebut berdistribusi normal tetapi memiliki varians yang heterogen, selanjutnya dilakukan uji-t' menggunakan 
Independent Sample T-Test dengan asumsi kedua varians heterogen (equal variances not assumed) dengan taraf signifikansi 0,05. Analisis uji korelasi dilakukan dengan menggunakan correlate bivariate dengan taraf signifikan $5 \%(\alpha=0,05)$.

HASIL DAN PEMBAHASAN

Tabel 4.20. Hasil ANOVA Dua Jalur Data $N$-Gain

Kemampuan Pemahaman Matematis

Tests of Between-Subjects Effects

Dependent Variable: Nilai Gain

\begin{tabular}{|c|l|l|l|l|l|}
\hline & $\begin{array}{l}\text { Type } \\
\text { III Sum } \\
\text { of } \\
\text { Squar } \\
\text { es }\end{array}$ & df & $\begin{array}{l}\text { Mean } \\
\text { Squar } \\
\text { e }\end{array}$ & F & Sig. \\
\hline $\begin{array}{c}\text { Correc } \\
\text { ted } \\
\text { Model }\end{array}$ & $.215^{\mathrm{a}}$ & 3 & .072 & 3.209 & .030 \\
\hline $\begin{array}{c}\text { Interce } \\
\text { pt }\end{array}$ & 9.492 & 1 & 9.492 & 425.37 & .000 \\
\hline Kelas & .632 & 1 & .632 & .915 & .000 \\
\hline $\begin{array}{c}\text { Gende } \\
r\end{array}$ & .189 & 2 & .094 & 4.234 & .019 \\
\hline $\begin{array}{c}\text { Kelas * } \\
\text { Gende } \\
r\end{array}$ & .427 & 1 & .427 & 1.476 & .000 \\
\hline
\end{tabular}

\begin{tabular}{|c|l|l|l|l|l|}
\hline Error & 1.272 & 57 & .022 & & \\
\hline Total & 10.937 & 61 & & & \\
\hline $\begin{array}{c}\text { Correc } \\
\text { ted } \\
\text { Total }\end{array}$ & 1.487 & 60 & & & \\
\hline
\end{tabular}

a. R Squared $=.144$ (Adjusted R Squared $=$ .099)

Berdasarkan hasil ANOVA dua jalur pada tabel 4.20, data N-Gain kemampuan komunikasi matematis ditinjau dari perbedaan gender, diperoleh nilai signifikan sebesar 0.019 maka Ho ditolak, karena nilai signifikan kurang dari $\alpha=0.05$. Maka dapat disimpulkan terdapat perbedaan kemampuan pemahaman matematis siswa yang memperoleh pembelajaran Brain Based Learning dengan siswa yang memperoleh pembelajaran konvensional ditinjau berdasarkan perbedaan gender. Hal ini menunjukan bahwa kemampuan pemahaman matematis siswa siswa laki-laki dan siswa perempuan dengan menggunakan pembelajaran Brain Based Learning lebih baik daripada siswa laki-laki dan siswa perempuan yang menggunakan pembelajaran konvensional. Hal ini didukung juga dengan hasil dari tabel statistik deskriftif kemampuan pemahaman matematis siswa dimana rata-rata kemampuan pemahaman matematis siswa laki-laki dan siswa perempuan memperoleh 
pembelajaran Brain Based Learning dengan siswa laki-laki dan siswa perempuan yang memperoleh pembelajaran konvensional berbeda.

Mega Fitria dengan judul "Analisis Kemampuan Pemahaman Konsep Matematis Siswa Yang Menggunakan Model Pembelajaran Reciprocal Teaching". Penelitian dilakukan di SMP Nasional Bandung. Dilihat dari rata-rata kemampuan akhir pemahaman konsep matematis siswa kelas eksperimen berbeda dengan rata-rata kemampuan awal pemahaman konsep matematis siswa kelas kontrol. Penelitian ini dapat dihubungkan kelas ekperimen sebagai pembelajaran Brain Based Learning dan kelas kontrol sebagai pembelajaran konvensoinal.

Ardiyansah dengan judul "Penerapan Model Pembelajaran Teams Games Tournaments (TGT) Untuk Meningkatkan Kemampuan Pemahaman dan Komunikasi Matematis Serta Kepercayaan Diri Belajar Siswa SMA". Penelitian dilakukan di SMA Negeri 1 Cabangbungin. Dilihat dari hasil jawaban siswa kelas eksperimen, siswa membuat model matematika terlebih dahulu memahami maksud dari masalah yang diberikan. Menyusun setiap data ke dalam tabel, lalu mengurutkan sesuai data yang bersesuaian dan menentukan model matematikanya. Sedangkan untuk kelas kontrol, terlihat siswa seperti menghafal konsep yang telah diberikan. Untuk pengolahan datanya sebenarnya tidak ada masalah, selama siswa tersebut memahami konsep dan mengkelompokan setiap data yang bersesuaian. Penelitian ini dapat dihubungkan kelas ekperimen sebagai pembelajaran Brain Based Learning dan kelas kontrol sebagai pembelajaran konvensional.

Tabel 4.28. Uji-t' Kecemasan Matematis Siswa Kelas Eksperimen dan Kelas Kontrol

\begin{tabular}{|c|c|}
\hline \multicolumn{2}{|c|}{ Independent Samples Test } \\
\hline \multicolumn{1}{|c|}{ Leve } \\
ne's \\
Test \\
for \\
Equa & \\
lity of & \\
Varia & \\
nces & t-test for Equality of Means \\
\hline
\end{tabular}




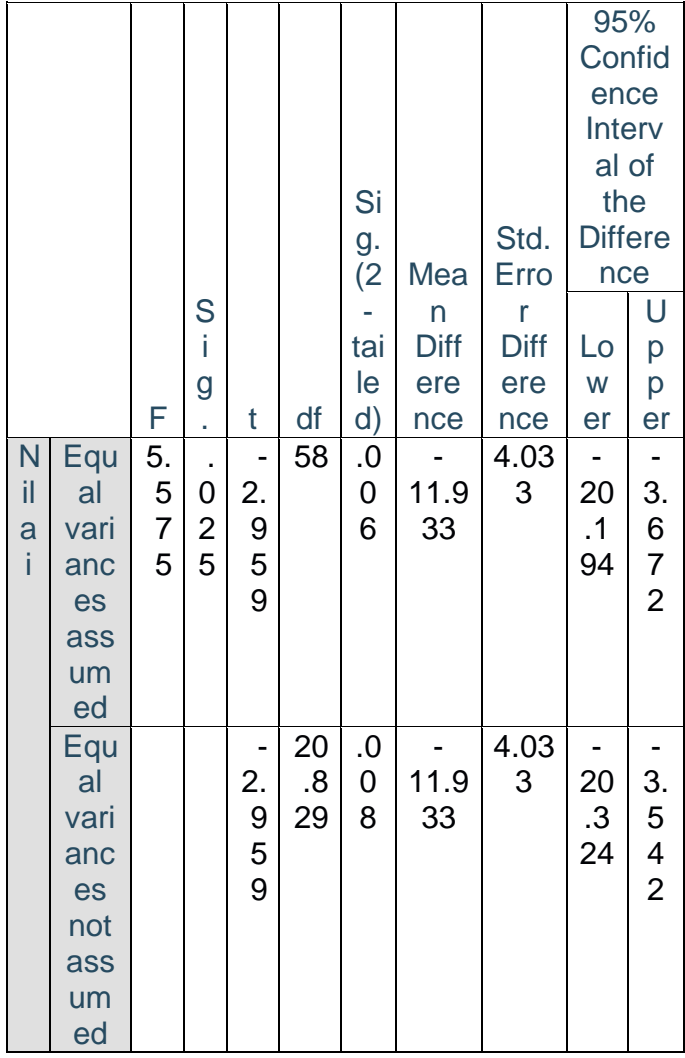

Berdasarkan hasil Uji-t' pada tabel 4.28, terlihat bahwa nilai signifikan yang diperoleh uji-t' yang ditinjau berdasarkan perbedaan gender yaitu $\frac{0,008}{2}=0,004<0,05$ maka $\mathrm{Ho}$ ditolak, sehingga dapat disimpulkan bahwa penurunan kecemasan matematis siswa yang memperoleh pembelajaran dengan strategi brain based learning lebih baik daripada siswa yang memperoleh pembelajaran konvensional ditinjau dari perbedaan gender.

Hasil yang diperoleh terlihat bahwa rata-rata skor kecemasan matematis siswa kelas eksperimen lebih besar dari pada kelas kontrol. Hal ini menunjukan bahwa pembelajaran dengan menggunakan metode Brain Based Learning memberikan konstribusi yang cukup baik dalam menurunkan kecemasan matematis siswa. Adanya perbedaan kecemasan matematis siswa yang menggunakan pembelajaran dengan Brain Based Learning dan siswa yang menggunakan pembelajaran konvensional disebabkan karena adanya pembelajaran yang melibatkan siswa, seperti siswa mempresentasikan hasil dari kerja kelompoknya didepan kelas dan siswa lain menanggapinya.

Hal ini diperkuat jawaban hasil wawancara, "Menurut kamu, pembelajaran yang bagaimana yang dapat membuatmu terbiasa untuk menurunkan kecemasan dalam menyelesaikan persoalan 
matematika?", siswa secara umum menjawab mereka senang belajar dengan cara dikelompokan atau diskusi kelompok sebab mereka merasa pembelajaran yang dikelompokkan membuat mereka lebih aktif dan mudah mengutarakan pendapatnya kepada teman kelompokknya dan membuat kecemasan matematis siswa menurun dalam mengerjakan dan memahami soalsoal matematika yang diberikan guru.

Ana Setiani dengan judul "Penerapan Model Pembelajaran Brain Based Learning untuk Meningkatkan Hasil Belajar Matematika Siswa SMP". Penelitian dilakukan di SMPN 2 Padaherang. Dilihat dari cara mengatasi pembelajaran Brain Based Learning agar lebih efektif yaitu pembelajaran dengan diselingi kuis matematika yang dilaksanakan dengan metode permainan dan senam otak, akan membuat siswa lebih memperhatikan soal-soal matematika dengan meyenangkan dan memantau aktifitas kelompok ke setiap kelompok. Sehingga dengan demikian siswa merasa termotivasi dalam belajar matematika dan kegaduhan yang sering terjadi di dalam kelas ketika pelaksanaan matematika di kelas akan terpantau.

Tabel 4.29. Hasil Uji Korelasi Data Kemampuan Pemahaman Matematis dan
Kecemasan Matematis Siswa yang Memperoleh

Model Pembelajaran Brain Based

Learning

\begin{tabular}{|c|c|c|c|c|}
\hline \multicolumn{5}{|c|}{ Correlations } \\
\hline & & $\underset{\text { KPM }}{\text { N_Gain }}$ & $\underset{\text { KKMain }}{\text { NKM }}$ & $\begin{array}{c}\text { Kecem } \\
\text { asan }\end{array}$ \\
\hline \multirow[t]{3}{*}{$\begin{array}{c}\text { N_Gain } \\
\text { KPM }\end{array}$} & $\begin{array}{c}\text { Pears } \\
\text { on } \\
\text { Correl } \\
\text { ation }\end{array}$ & 1 & $.456^{*}$ & -.052 \\
\hline & $\begin{array}{l}\text { Sig. } \\
(2- \\
\text { tailed) }\end{array}$ & & .011 & .785 \\
\hline & $\mathrm{N}$ & 30 & 30 & 30 \\
\hline \multirow[t]{3}{*}{$\begin{array}{c}\text { N_Gain } \\
\text { _KKM }\end{array}$} & $\begin{array}{c}\text { Pears } \\
\text { on } \\
\text { Correl } \\
\text { ation }\end{array}$ & $.456^{\star}$ & 1 & -.051 \\
\hline & $\begin{array}{l}\text { Sig. } \\
(2- \\
\text { tailed) }\end{array}$ & .011 & & .790 \\
\hline & $\mathrm{N}$ & 30 & 30 & 30 \\
\hline \multirow[t]{3}{*}{$\begin{array}{c}\text { Kecema } \\
\text { san }\end{array}$} & $\begin{array}{c}\text { Pears } \\
\text { on } \\
\text { Correl } \\
\text { ation }\end{array}$ & -.052 & -.051 & 1 \\
\hline & $\begin{array}{l}\text { Sig. } \\
(2- \\
\text { tailed) }\end{array}$ & .785 & .790 & \\
\hline & $\mathrm{N}$ & 30 & 30 & 30 \\
\hline
\end{tabular}


${ }^{*}$. Correlation is significant at the 0.05 level (2tailed).

Berdasarkan hasil uji korelasi pada tabel 4.29 menggambarkan bahwa nilai signifikan antara kemampuan pemahaman matematis dan kecemasan matematis siswa memperoleh nilai sig. $>\alpha(\alpha=0,05)$, maka $\mathrm{H}_{\mathrm{o}}$ diterima. Artinya tidak terdapat korelasi antara kemampuan pemahaman matematis dan kecemasan matematis siswa dalam pembelajaran yang memperoleh strategi pembelajaran Brain Based Learning ditinjau dari perbedaan gender.

Dari hasil analisis perhitungan dengan uji korelasi ditemukan bahwa terdapat korelasi antara kemampuan pemahaman matematis dan kecemasan matematis. Artinya semakin tinggi kemampuan pemahaman matematis maka akan berpengaruh terhadap penurunan kecemasan matematis siswa, sehingga adanya hubungan yang positif antara kemampuan pemahaman matematis dan kecemasan matematis siswa. Jika dilihat dari hasil analisis, kemampuan pemahaman matematis dan kecemasan matematis siswa tidak jauh berbeda. Menurut Anita (2011), dalam penelitiannya tentang kecemasan matematika siswa SMP mengatakan bahwa tingkat kecemasan yang paling tinggi dialami siswa adalah kecemasan ketika ujian matematika. Artinya kecemasan matematis pada diri siswa sangat mengkhawatirkan. Dalam penelitian ini kemampuan pemahaman berperan penting dalam penurunan kecemasan matematis siswa sehingga menyebabkan adanya hubungan yang positif antara kemampuan pemahaman matematis dan penurunan kecemasan matematis siswa.

Menurut Dahlan (2015), mengemukakan bahwa guru sebaiknya menggunakan strategi Brain Based Learning dalam pembelajaran matematika karena mampu meningkatkan kemampaun pemahaman, komunikasi matematis dan dapat menurunkan kecemasan matematis siswa. Kecemasan merupakan suatu kondisi yang hampir pernah dialami oleh semua siswa. Ketika kecemasan matematika itu sudah berlebihan, maka akan mneghambat siswa dalam belajar dan mengembangkan kemampuan matematikanya. Menurut Hadi (Fadliani, 2015) menyatakan bahwa salah satu alasan perlunya para siswa belajar matematika adalah bahwa matematika merupakan alat komunikasi yang sangat kuat, teliti, dan tidak membingungkan. Oleh karena itu, kemampuan komunikasi matematis perlu dikembangkan melalui pembelajaran agar siswa mampu 
mengkomunikasikan ide, pikiran, ataupun pendapat dalam belajar matematika.

\section{PENUTUP}

\section{Simpulan}

Berdasarkan hasil temuan dan analisis data hasil penelitian, peneliti memperoleh kesimpulan sebagai berikut: (1) Peningkatan kemampuan pemahaman matematis siswa yang memperoleh pembelajaran dengan strategi Brain Based Learning lebih baik daripada siswa yang memperoleh pembelajaran konvensional ditinjau dari perbedaan gender; (2) Siswa yang menggunakan pembelajaran dengan strategi Brain Based Learning mempunyai tingkat kecemasan yang lebih rendah dibandingkan dengan siswa yang menggunakan pembelajaran konvensional; (3) Tidak terdapat hubungan antara kecemasan matematis siswa terhadap kemampuan pemahaman matematis siswa.

\section{Saran}

Berdasarkan hasil temuan dan kesimpulan pada penelitian ini. Peneliti mengajukan beberapa saran sebagai berikut: 1) Pembelajaran di kelas Brain Based Learning, dapat dijadikan sebagai pembelajaran yang dapat digunakan dalam pembelajaran matematika untuk meningkatkan kemampuan pemahaman matematis dan mengurangi kecemasan matematis siswa. 2) Bagi para guru matematika, dalam pembelajaran di kelas sebaiknya memperhatikan adanya indikasi kecemasan matematis pada diri siswa. Karena kecemasan matematis bisa mempengaruhi tinggi atau rendahnya kemampuan berpikir matematis siswa khusunya kemampuan pemahaman matematis. 3) Bagi peneliti selanjutnya, penelitian ini dapat dilanjutkan untuk melihat pengaruh di kelas Brain Based Learning. Kemampuan matematis yang lainnya, seperti kemampuan pemecahan masalah dan berpikir kreatif matematis. 4) Diperlukan penelitian yang lebih mendalam tentang kecemasan matematis siswa, terutama yang mengkaji faktor-faktor apa saja yang mempengaruhi kecemasan matematis dan bagaimana menghilangkan kecemasan matematis pada siswa. 


\section{DAFTAR PUSTAKA}

Anita, I. W. 2011. Pengaruh Kecemasan (Mathematics Anxiety) terhadap Kemampuan Pemecahan Masalah dan Koneksi Matematis Siswa SMP. Jurnal Pendidikan Matematika. 3(1): 125-132.

Ardiyansah, N. (2021). Penerapan Model Pembelajaran Teams Games Tournaments Meningkatkan (TGT) Untuk Pemahaman dan Komunikasi Matematis Serta Kepercayaan Diri Belajar Siswa SMA (Doctoral dissertation, Universitas Pasundan).

Dahlan, T. 2015. Tesis. Kemampuan Pemahaman Matematis Komunikasi Matematis dan Kecemasan Matematis Siswa MTs dalam Brain Based Learning. Universitas Pendidikan Indonesia. Bandung: tidak diterbitkan.

Fadliani, P. 2015. Tesis. Meningkatkan Kemampuan Pemahaman, Komunikasi, dan Kemandirian Belajar Siswa SMP dengan Menggunakan Model Pembelajaran Berbasis Masalah.
Universitas Pendidikan Indonesia. Bandung: tidak diterbitkan.

Fitria, M., Kartasasmita, B., \& Supianti, I.I. 2019. Analisis Kemampuan Pemahaman Konsep Matematis Siswa Yang Menggunakan Model Pembelajaran Reciprocal Teaching. Jurnal Prisma. 8(2): 124-134.

Hellum-Alexander, A. 2010. Effective Teaching Strategies for Alleviating Math Anxiety and Increasing Self-Efficacy in Secondary School. A Thesis submitted in partial fulfillment of the requirements for the degree Master in Teaching, The Evergreen State College.

Indrawan. R., Yaniawati. P. (2014). Metodologi Penelitian Kuantitatif, Kualitatif, dan Campuran untuk Managemen, Pembangunan dan Pendidikan. Bandung: PT. Refika Aditama.

Kariadinata, R., Yaniawati, R. P., Sugilar, H., \& Riyandani, D. 2019. Learning motivation and mathematical understanding of students of islamic 
junior high school through active knowledge sharing strategy. Infinity Journal,8(1), 31-42.

Maloney, E. A., and S. L. Beilock. 2012. "Math Anxiety: Who Has It, Why It Develops and How to Guard against It." Trends in Cognitive Sciences. 16 (8): 404-406.

Rosmanita. 2014. Tesis. Pengaruh Model Pembelajaran Tipe The Power Of Two Terhadap Peningkatan Kemampaun Pemahaman Matematis dan Penurunan Kecemasan Matematika Siswa SMP. Universitas Pendidikan Indonesia. Bandung: tidak diterbitkan.

Setiani, A. 2018. Penerapan Model Pembelajaran Brain Based Learning untuk Meningkatkan Hasil Belajar Matematika Siswa SMP. Symmetry: Pasundan Journal of Research in Mathematics Learning and Education. 3(1): 8-16.

Widyantara dkk. 2014. Pembelajaran berbasis otak berbantuan media visual berpengaruh terhadap keterampilan menulis deskripsi bahasa indonesia. e-
Journal Mimbar PGSD Universitas Pendidikan Ganesha. 2(1): 1-10.

Qohar, A. 2011. Mathematical Communication: What And How To Develop It in Mathematics Learning? Proceeding International, Seminar and the Fourth National Conference on Mathematics Education. Yogyakarta: 21-23 Juli 2011. 